\title{
Analysis of Implementation Safety and Health Occupational Management System in Kertosono General Hospital
}

\author{
Dian Hadi Purnomo ${ }^{1}$, \\ Indasah $^{2}$, Byba Melda ${ }^{2}$ \\ ${ }^{1}$ Magister of Health Study \\ Program of STIKes Surya Mitra \\ Husada Kediri \\ ${ }^{2}$ Lecturer of STIKes Surya Mitra \\ Husada Kediri \\ purnomodianhadi@gmail.com
}

Received: April 19, 2018

Accepted : May 08, 2018

Published : May 11, 2018

\section{ABSTRACT}

Kertosono Regional General Hospital has a high risk exposure and is the biggest hospital in Kertosono area, Nganjuk regency, so to prevent accidents and occupational diseases, it is necessary to manage $\mathrm{K} 3$ management through the implementation of the implementation of Occupational Safety and Health Management System (SMK3RS). This study aims to get a picture of the implementation or implementation of Occupational Safety and Health Management System (SMK3RS) implemented in RSUD Kertosono. The research design used was qualitative research with thematic analysis and by using observation method, in-depth interview, and documentation. Sampling technique used is purposive sampling with informant as many as ten people are structural hospital officials who have worked in RSUD Kertosono minimum five years and above. This research resulted that K3 Management System in RSUD Kertosono not yet the establishment of K3 Committee because not yet have $\mathrm{K} 3$ general expert, in terms of policy and commitment of $\mathrm{K} 3$ even though only in the form of oral speech, process of implementation of SMK3RS which have been run although not maximal, support factor and factor which inhibits, efforts are made to reduce barriers in the implementation process of SMK3RS, the impact of SMK3RS implementation, and the desired expectation in the implementation of SMK3RS in RSUD Kertosono. This study concludes that basically OSH program has been run well according to legislation, although $\mathrm{K} 3$ still not become work culture which will create the creation of Zero accident in work environment specially in hospital.

Keywords : Hospital, OHS policy, OSH program, SMK3.

Copyright @ 2018 STIKes Surya Mitra Husada

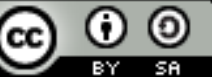

This is an open-acces article distributed under the terms of the Creative Commons Attribution-ShareAlike 4.0 International License. 


\section{INTRODUCTION}

Health and Safety (OSH) is an effort to protect workers and others entering the workplace against the hazards of accidents. The purpose of $\mathrm{K} 3$ is to prevent, reduce, even nullify the risk of occupational diseases and accidents (CAC) and improve the health of workers so that work productivity increases. In the Law of the Republic of Indonesia Number 36 Year 2009 on health, work health efforts are shown to protect workers to live healthy and free from health problems and bad influences caused by workers. (Mitrison, 2010).

Kertosono Regional General Hospital is a referral hospital that is expected to provide the best health services. However, based on the findings are still found the occurrence of work accidents and the incidence of occupational diseases such as the transmission of disease to officers due to errors in work and the existence of various accidents due to facilities, equipment and work environment overall problem related to the implementation of the K3 management system is less good. (Kepmenkes, 2010).

Regional General Hospital (RSUD) Kertosono Nganjuk Regency is one of the Hospital owned by the local government Nganjuk regency located in District Kertosono. This hospital is the only state hospital owned by the local government of the regency and is a hospital dedicated to residents of Kertosono district and surrounding areas. And on September 4, 2017 the services were moved in a new building.

Based on the preliminary survey that has been done in RSUD Kertosono Nganjuk District, the data of occupational diseases in hospitals Kertosono can be calculated based on the percentage of the total number of labor as much as 321 workers, both civil servants and contract workers. Based on data from RSUD Kertosono 2015, occupational diseases that have no abnormalities or do not cause work-related diseases as much as $95.7 \%$ or as many as 307 workers do not experience occupational diseases, ISPA disease as much as $1.05 \%$ or as many as 4 workers, heart disease as much as $2.09 \%$ or as many as 7 workers, TB disease post (Tuberculosis) as much as $1.07 \%$ or as many as 3 workers, with hepatitis B disease as much as $0.07 \%$. The disease obtained from the data comes from the results of medical records all employees RSUD Kertosono. Heart disease and tuberculosis (lung), and hepatitis B is a disease that has suffered labor before becoming an employee or employee at RSUD Kertosono.

While the data of accidents due to work at RSUD Kertosono in 2015, as many as $47.6 \%$ of accidents that occurred is impaled needle, as many as $16.7 \%$ of accidents that occurred is dropped, as many as $8.7 \%$ of accidents that occur are chemically contaminated, as much as $9,6 \%$ of accidents that occur are pinched, as much as $9.6 \%$ of accidents that occur is cut sharp objects, and $7.8 \%$ of accidents that occur is burned.

While through the process of interviewing with 3 structural personnel, obtained information of which part of K3 not yet formed, all problem about K3 still overcome by MFK part appointed by SK Director of Hospital and director of RSUD Kertosono. As a long standing hospital and state hospital owned by the local government of Nganjuk Regency has been accredited. The accreditation should be done in 2018, but since the RSUD is relocated in Jalan Panglima Sudirman no. 41 District Kertosono Nganjuk, then accreditation postponed in 2020. This is why all the workers who are competent in the implementation of the management system K3RS still do the rearrangement and new improvements. The purpose of this study is to analyze the implementation of Occupational Safety and Health Management System (SMK3) in RSUD Kertosono. 


\section{METHOD}

In this research using qualitative method with phenomenology approach with focus of its research is directed to know Implementation of Occupational Safety and Health Management System (SMK3) in RSUD Kertosono in depth. Location of research in this research is in District Nganjuk East Java precisely in District Kertosono that is in RSUD Kertosono newly relocated on 1 September 2017 become the only General Hospital in Kertosono which have same facility with type class hospital A. Time of research done during December 2017.

Sampling technique in this research use purposive sampling. Triangulation is amounted to three (3) persons, namely director of RSUD Kertosono, Chairman of MFK, and Head of Administration. They became resource persons.

The data retrieval process with semi-structured in-depth interview method was done to employees or employees of RSUD Kertosono who had worked for more than five years, where the informant was asked by the researcher and the result of the informant's answer was directly recorded into the mobile phone as recording device and filled out the cake answerer for shooting informant using camera phone by not showing the face of the informant (with the knowledge of the informant).

\section{RESULT}

The process of implementation or implementation of Occupational Safety and Health Management System (SMK3) in RSUD Kertosono Nganjuk

The result of this research is that the commitment and policy of RSUD Kertosono Nganjuk Regency, initially only in the form of oral speech and not yet SK-kan, OSH committee has not been formed because not yet have general health expert, so P2K3 can not be SK-kan by director of RSUD Kertosono, so that the implementation of Occupational Safety and Health Management System (SMK3) in RSUD Kertosono is still held by the Medical Service (Yanmed).

The development process of implementation or implementation of Occupational Safety and Health Management System (SMK3) in RSUD Kertosono Nganjuk

The results of this study are marked by the installation of alarms in every room, the installation of marking signs, and K3 signs in each room, where the waste separated according to the rules of use, the sprinkler in every room, the existence of fire extinguishers light.

The inhibiting factor of the implementation process or implementation of Occupational Safety and Health Management System (SMK3) in RSUD Kertosono Nganjuk.

The results of this study are marked by the lack of knowledge level of K3 from hospital employees is still lacking, marked by lack of human resources so that the $\mathrm{K} 3$ team is still held by people or functional personnel who work in the medical or yanmed service, marked by hospital employees who less complacent about K3 in hospitals especially the use of PPE (personal protective equipment), marked by not yet formation of K3 team which has not been declared by hospital side especially by director of Kertosono regional general hospital, marked by relocation of general hospital of Kertosono area from Jalan Supriyadi moved to Jalan Panglima Sudirman Kecamatan Kertosono. 
Application of the implementation process or implementation of Occupational Safety and Health Management System (SMK3) in RSUD Kertosono Nganjuk District

The results of this study are marked by the standard operating procedure (SOP) in the implementation or use of all hospital programs.

Efforts are used to reduce barriers in the process of implementation or implementation of Occupational Safety and Health Management System (SMK3) in RSUD Kertosono Nganjuk

The results of this study are marked by the existence of recruitment plan employees or employees, marked by the plan to increase the cost to equip facilities and infrastructure K3 at the hospital, marked by scheduling regularly appointed employee, marked by making SK team $\mathrm{K} 3$ at the hospital marked by makekan board or writing either indoors or outdoors.

The expected impacts in the process of implementation or implementation of Occupational Safety and Health Management System (SMK3) in RSUD Kertosono Nganjuk

The results of this study are expected to minimize accidents due to work and occupational diseases, can minimize the risk of harm that occurs, and can reduce the level of safety and health hazard.

Desired expectations in the process of implementation or implementation of Occupational Safety and Health Management System (SMK3) in RSUD Kertosono Nganjuk

The results of the study also found that there are informants who hope that the implementation of Occupational Safety and Health Management System (SMK3) in this hospital is not only a liability but has become a work culture.

\section{DISCUSSION}

The implementation process of the implementation of Occupational Safety and Health Management System (SMK3) in RSUD Kertosono Nganjuk

Research focus 1 is K3 Management System (SMK3) in RSUD Kertosono, which will be described in the theme below: Management of RSUD Kertosono refers to Balance Scored Card (BSC) strategy is a contemporary management tool used to boost organizational performance through financial perspective, customer, internal business processes and employee empowerment and growth.

The steps in developing a health and safety management system are divided into seven, namely legislation, policies, organizations, plans, implementation, measuring and monitoring, and auditing of occupational safety and health management systems. Regulations and standards of occupational safety and health management systems prevailing within the company are made by a team set up specifically by the company. The results of identification that have been done then arranged in the rules and guidelines implementation of occupational safety and health at the company (Azmi, 2009).

In the international environment the standards of occupational safety and health are determined by the association of various standardization bodies incorporated into Occuptional Health and Safety Assessment Series 18001: 2007 (OHSAS 18001: 2007). In OHSAS 18001: 2007 provides six criteria of safety management and occupational health that must be implemented by companies with international standards. These six criteria include applications and operations which include: human resources, roles, responsibilities, accountability, and authority. So that human resources are really needed in the 
implementation of occupational safety and health management system (SMK3), whereas in hospitals Kertosono is still very limited in human resources so that RSUD Kertosono does not have $\mathrm{K} 3$ committee and not yet $\mathrm{P} 2 \mathrm{~K} 3$ formation because there is still limited human resources who is in the hospital.

The development in the implementation process of the Management System of Occupational Safety and Health (SMK3) in RSUD Kertosono Nganjuk

The focus of research 2 is the existence of Commitment Management System Occupational Safety and Health (SMK3) in RSUD Kertosono. Commitment and policy of RSUD Kertosono about K3 implementation initially only in the form of oral speech and not yet SK. Safety is an effort to create an atmosphere of safe working, free from all threats of danger, such as: fire, occupational diseases, work-related disabilities, and death from work.

In the above explanation indicates that the commitment of hospital leaders about $\mathrm{K} 3$ with the issuance of Policy with the formation of working group implementer of K3RS that is P2K3 expected existence of worker and employee and also work organization therein to improve safety and health (K3) in accordance with Permenaker No. 04 / MEN / 1987. The K3RS program is pursued for control of potential hazards, improving the productivity and quality of health services through continuous and sustainable processes. In general, the established P2K3 team is responsible for the implementation of the K3RS, but P2K3 has not yet been established and has not yet been drawn up by the Decree.

Factors inhibiting the implementation process of Management System Occupational Safety and Health (SMK3) in RSUD Kertosono Nganjuk

Factors inhibiting the safety and health management system are divided into several points. The points are the absence of requirements from consumers regarding the proof of implementation of safety management system and occupational health. The impact of the economic crisis can also hinder the creation of safety and health management systems. There are no consequences for companies that delay and refuse the implementation of audits of occupational safety and health management systems. The lack of company, especially the hospital because of the company's ignorance and audit fees that are considered to burden the company. Frame coordination of the implementation of other engineering departments audit has not materialized (Azmi, 2009).

From the informant's speech explained that the factors that hinder the implementation of health and safety management system in RSUD Kertosono include the lack of knowledge about K3, According Sedarmayanti (2009) consists of three factors of safety indicators of work environment factors, human factors or employees which includes both physical and mental factors, knowledge and skills in this regard is a lack of attention to safe and good working methods, wrong habits, and lack of experience, and attitude. And this is due to lack of socialization about K3 to all hospital employees.

\section{Application of Implementation of Occupational Safety and Health Management System (SMK3) in RSUD Kertosono}

A good and healthy company is a company that always pay attention to the condition of its employees, in this case the safety of its employees. The implementation of an optimal employee safety program for employees is directly related to employee work productivity, since the implementation of work safety program is one way to motivate employees to improve their work productivity. Motivation that will arise from employees to work as well as possible if they feel safe and comfortable in carrying out their work without any risk that can threaten the safety of his soul, in addition employees will also be happy because they feel paid attention by the company where they work. However, if the work safety program is not implemented intensively and optimally, it can decrease the enthusiasm 
and passion of employees because they are afraid to take risks to endanger their lives and of course because they feel not paid attention by the company where they work.

Waste handling activities according to Law no. 18 Year 2018 includes: segregation and segregation of waste in accordance with the type, quantity, and or nature of waste, collection in the form of removal and removal of waste from waste sources to temporary shelters or integrated waste processing sites; transport in the form of carrying waste from sources and / or from a temporary garbage collection site or from an integrated waste treatment site leading to a final processing site, processing in the form of changing the characteristics, composition, and amount of waste, final processing of waste in the form of return of waste and / or the residue of the previous processing to the environment medium safely.

Efforts that are used in reducing the barriers of the implementation process of Occupational Safety and Health Management System (SMK3) in RSUD Kertosono Nganjuk

Research focus 4 will be elaborated with Health and Safety Management System Evaluation Process conducted in hospital for K3 can run in accordance with agreed commitments for monitoring at RSUD Kertosono is good, where in hospitals Kertosono monitoring process is still done by the hospital interen especially when the accreditation will be done, and the appointed party to do this monitoring will then report to be the next evaluation material. Then follow up from the existence of the internal monitoring in accordance with interviews with informants, the first thing done during the monitoring is to check in accordance with the provisions. Reporting or documentation will then be subsequently evaluated. The same study was conducted by Nirtya Sari (2013). Occupational safety and health inspection is very necessary and effective to be done in the framework of efforts to develop safety and health in the field.

\section{The impact of the implementation process of Occupational Safety and Health Management System (SMK3) in RSUD Kertosono Nganjuk}

Research focus 5 will be described in accordance with the sub theme below: After implementing the OSH Management System at the hospital, the impacts are obtained, among others, according to the informant's speech 1 that by committing to implement K3RS, it can minimize the danger and risk that happened, and from the results of research and discussion shows that implemantasi SMK3 in RSUD Kertosono not in accordance with the guidance of K3 Management System and existing government regulation, that is all health industry or private company have to have expert of K3. In RSUD Kertosono K3 team is still held by the Medical Service and has not had a K3 committee and has not formed P2K3 because it does not have a general $\mathrm{K} 3$ expert.

\section{CONCLUSION}

Management of RSUD Kertosono refers to Balance Scored Card (BSC) strategy, a contemporary management tool used to boost organizational performance through financial, customer, internal business process and empowerment and employee growth. Commitment and Policy of Occupational Safety and Health Management System (SMK3) in RSUD Kertosono is still implemented through verbal stakeholders and has not been determined any decisions or SK in writing about K3, just in the form of SOP. And the implementation of Occupational Safety and Health Management System (SMK3) in RSUD Kertosono has been well realized. 


\section{SUGGESTION}

For Further Researcher, it is expected to develop the research by doing triangulation method so that new phenomena can arise.

\section{REFERENSI}

Andreane, M. (2004). Desentralisasi Manajemen Sumber Daya Manusia Kesehatan : Pengalaman Implementasi di DIY Yogyakarta. Seminar Nasional 3 tahun Pelaksanaan Desentralisasi Kesehatan di Indonesia PKPK; FK-UGM.

Anonim. (2004). Undang-Undang Ketegakerjaan Lengkap. Jakarta : Sinar Grafika.

Anonim. (2006). Advokasi sebagai Alat Perubahan, Pusat Kesehatan Kerja. http//www.depkes.go.id. diperoleh tanggal 27 Mei 2010.

Anonim. (2010). Undang-Undang Kesehatan dan Rumah Sakit 2009. Yogyakarta : Pustaka Yustisia.

Anonim. (2013). Himpunan Peraturan perundang-Undangan Perlindungan dan pengelolaan Lingkungan Hidup. Bandung : Fokus Media.

Arikunto. S. (2005). Manajemen Penelitian. Jakarta : Rineka Cipta.

Azwa, A. (2010). Pengantar Administrasi Kesehatan. Jakarta : PT Bina Rupa Aksara.

Barry, S.L., \& David, H.W. (1994). Occupational Health Recognizing and Preventing WorkRelated Disease. USA : Third Edition.

Cahyono. (2012). Perbedaan Sikap Penyelenggaraan Keselamatan dan Kesehatan Kerja (K3) di RS. Dr. Sarjito Yogyakarta. Yogyakarta : Tesis Sarjana S2 UGM.

Chaniago. (2002). Kamus Lengkap Bahasa Indonesia. Bandung : Pustaka Setia.

Chaplin, JP. (2008). Kamus Lengkap Psikologi. Jakarta : PT. Raja Grafindo.

Depkes. (2014). Profile Kesehatan Indonesia. Retrieved Pebruari 10, 2017, from www.depkes.go.id/download/pusdatin.

Depkes. (2010). Standar Kesehatan dan Keselamatan Kerja di Rumah Sakit. Jakarta: Kementerian Kesehatan RI.

Depkes. (2010). Modul Pelatihan Kesehatan Kerja bagi Petugas Kesehatan. Jakarta : Kementerian Kesehatan RI.

Depkes. (2001). Panduan Teknis Upaya Kesehatan Kerja di Rumah Sakit. Jakarta: Kementerian Kesehatan RI.

Depnaker. (2009). Himpunan Peraturan Perundangan - undangan Keselamatan dan Kesehatan Kerja. Jakarta : Direktorat Pengawasan Norma K3.

Dinkes. (2014). Profil Kesehatan Provonsi Jawa Timur. Surabaya : Dinkes Jatim.

Djaali. (2007). Psikologi Pendidikan. Jakarta : Bumi Aksara. 
Hasyim, H. (2005). Manajemen Hiperkes dan Keselamatan Kerja di Rumah Sakit (Tinjauan Kegiatan Keselamatan dan Kesehatan Kerja di Institusi Sarana Kesehatan. Jurnal Manajemen Hiperkes dan Keselamatan Kerja Vol. 8 No. 2 Juni 2005.

Kemenkes, RI. (2014). INFODATIN: Pusat Data dan Informasi Kementerian Kesehatan RI. Jakarta : Kemenkes RI.

Kemenkes, RI. (2017). INFODATIN: Pusat Data dan Informasi Kementerian Kesehatan RI. Jakarta : Kemenkes RI.

Keputusan Menteri Kesehatan Republik Indonesia Nomor : 432/Menkes/SK/IV/2007 Tentang Pedoman Manajemen Keselamatan dan Kesehatan Kerja (K3) di Rumah Sakit.

Lee, Ruli. (2013). Keselamatan dan Kesehatan Kerja. Makalah Tentang Keselamatan dan Kesehatan kerja (MK3LH) 27 Agustus 2013.

Mitrison. (2010). Sistem Manajemen Keselamatan dan Kesehatan Kerja (SMK3) di Lapangan dan Laboratorium. Deperindag. Badan Penelitian dan Pengembangan Industri dan Perdagangan Pontianak.

Moleong, \& Lexy, J. (2007). Metodologi Penelitian Kualitatif, Penerbit PT Remaja Rosda karya Offset. Bandung.

Muninjaya. (2004). Manajemen Kesehatan, Edisi ke-2. Jakarta : EGC.

Notoatmodjo, S. (2003). Pendidikan dan Perilaku Kesehatan. Jakarta : Rineka Cipta. 2007. Kesehatan Masyarakat Ilmu dan Seni. Jakarta : Rineka Cipta.

Peraturan Menteri Tenaga Kerja No.: PER.05/MEN/1996 Tentang Sistem Manajemen Keselamatan dan Kesehatan kerja.

Peraturan Menteri Tenaga Kerja Nomor : KEP 19/M/BW/97 Tanggal 26 Februari 1997 Tentang Pelaksanaan Audit Sistem Manajemen Keselamatan dan Kesehatan Kerja.

Phoon, W.O. (1998). Practical Occupational Health. JBW Printers and Binders Pte. Tld. Singapure.

Profil Rumah Sakit Umum Daerah Kertosono Tahun 2017.

Siswanto, E. (2001). Sistem Manajemen Keselamatan dan Kesehatan Kerja. Seminar Nasional K3 dan ISO 14000 bagi kegiatan industri. FTL. Semarang : Universitas Diponegoro.

Soehatman, R. (2010). Sistem Manajemen Keselamatan dan Kesehatan Kerja OHSAS 18001. Jakarta : Dian Rakyat.

Suardi, R. (2005). Sistem Manajemen Keselamatan dan Kesehatan Kerja. Panduan Penerapan Berdasarkan OHSAS 18001 \& Permenaker 05/1996. Jakarta : Lembaga Manajemen PPM.

Sugiyono. (2008). Metode Penelitian Kuantitatif, Kualitatif, $R \&$ G. Bandung : Alfabeta.

Suhita. (2005). Apa itu Dukungan Sosial. http://www.masbow.com/2009/08/apa-itudukungan-sosial.html. Diakses tanggal 15 Januari 2017. 